\title{
Global Procurement Law in Times of Crisis: New Buy American Policies and Options in the WTO Legal System
}

John Linarelli

Touro Law Center, jlinarelli@tourolaw.edu

Follow this and additional works at: https://digitalcommons.tourolaw.edu/scholarlyworks

Part of the Comparative and Foreign Law Commons, Contracts Commons, International Law Commons, International Trade Law Commons, and the Transnational Law Commons

\section{Recommended Citation}

John Linarelli, Global Procurement Law in Times of Crisis: New Buy American Policies and Options in the WTO Legal System, in THE WTO REGIME ON GOVERNMENT PROCUREMENT: CHALLENGE AND REFORM (Sue Arrowsmith \& Robert Anderson eds., 2011).

This Book Chapter is brought to you for free and open access by the Faculty Scholarship at Digital Commons @ Touro Law Center. It has been accepted for inclusion in Scholarly Works by an authorized administrator of Digital Commons@ Touro Law Center. For more information, please contact Iross@tourolaw.edu. 
S. Arrowsmith and R. D. Anderson (eds.), The WTO Regime on Government Procurement: Challenge and Reform (forthcoming CUP)

\section{Chapter XX}

\section{Global Procurement Law in Times of Crisis: New Buy American Policies and Options in the WTO Legal System}

John Linarelli*

\section{Introduction}

What should governments do to protect their citizens in a global economic crisis? National economies are interdependent and economic risk is systemic on a global scale, but economic policy remains pervasively national in scope. ${ }^{1}$ Fiscal policy is one tool that some economists advocate to counteract economic downturns. ${ }^{2}$ Fiscal policy, however, has not been the subject

\footnotetext{
* Associate Dean for Academic Affairs and Professor of Law, University of La Verne College of Law, Ontario California, USA, jlinarelli@laverne.edu.

${ }^{1}$ For an influential account of the notion of systemic risk, see S. L. Schwarcz, 'Systemic Risk', Georgetown Law Journal, 97 (2008), 193. Although the G20 has met to discuss coordination, regulatory designs are pervasively national in orientation. For a US example, see Fact Sheet: Administration's Regulatory Reform Agenda Moves Forward: Systemic Risk Legislation Sent to Capitol Hill, available at www.treas.gov/press/releases/tg227.htm (22 July 2009) (accessed 23 Aug. 2009).

2 See J. B. DeLong, 'The Long Pedigree of Interventionism', The Economists' Voice, July 2009; P. Krugman, 'Protectionism and Stimulus', The New York Times, February 1, 2009; C. Romer and J. Bernstein, 'The Job Impact of the American Recovery and Reinvestment Plan', 9 January 2009; P. Krugman, 'European macro algebra', The New York Times, 14 December 2008; J. B. Taylor, 'The State of the Economy and Principles for Fiscal Stimulus', Testimony before the Committee on the Budget, US Senate, 19 November 2008.
} 
of collective action at the global level, and if it has, states accomplish it in ad hoc political (as opposed to legal) arrangements in response to particular crises. More generally, states retain primary responsibilities for structuring institutions to promote economic justice for their citizens. Despite moves towards conceptualizing justice as a global concern, justice remains primarily a concern for domestic constitutional orders. Fiscal policy and economic justice are widely understood as the domain of the political orders of states, national in their reach, tied to notions of statehood. These features of the state are in tension with the increasingly complex interdependencies of states and with the dense web of treaty commitments they have undertaken, particularly in economic matters.

To put this tension in more concrete terms, consider the expenditure of approximately US \$181.7 billion in today's dollars by the US government's Works Progress Administration (WPA) in the mid-1930s, intended to stimulate the US economy during the Great Depression. In the 1930s, efficiencies associated with contracting out by government were not well understood. The WPA engaged in direct government provision of construction and other services. It employed up to 3.3 million in $1938 .^{3}$ But what if at least some of those billions were spent through government procurement? At the time, there was no concern about the effects of such expenditures on the international trade obligations of the US. The bilateral treaties of friendship, commerce, and navigation of the day did not deal with government procurement. In fact, the US Buy American Act was passed in 1933. Moreover, government procurement of that earlier time was much less disciplined and professionalized than it is today, and using procurement for

\footnotetext{
${ }^{3}$ See N. Taylor, American-Made: The Enduring Legacy of the WTO: When FDR Put the Nation Back to Work, (New York: Random House, 2008).
} 
political purposes was accepted or at least tolerated. Nor did governments have to worry much about the substantial multinational nature of firms and how global supply chains affect public procurement. ${ }^{4}$

Much has changed since the Great Depression. While the WPA's mandate was direct provision of construction and services, governments now outsource much of that activity to contractors. A substantial set of international obligations constrains governments from protecting their procurement markets from international competition. These are the plurilateral Agreement on Government Procurement (GPA) in the WTO system and various commitments found in regional and bilateral free trade agreements (FTAs), such as, for the US at least, the North American Free Trade Agreement, the Caribbean Basin Trade Initiative, and FTAs with Australia, Bahrain, the Dominican Republic (the Central American Free Trade Agreement), Chile, Israel, Morocco, Oman, Peru, and Singapore. ${ }^{5}$ The GPA and FTA commitments reflect a clear but halting trend towards liberalization of procurement markets, though attempts at achievement of multilateral commitments in the WTO have not yet been successful but eventually will have to

\footnotetext{
${ }^{4}$ The initial attempt in the US to restrict procurement of information technology to improve internet broadband access illustrates the problems that can arise when governments attempt to impose buy national requirements on global procurement supply chains. As discussed below, the procuring agency in this case, the National Telecommunications and Information Administration, ultimately waived the Buy American provisions. See 'Cisco and Alcatel Oppose “Buy American” Broadband Requirements', The New York Times, 16 June 2009.

${ }^{5}$ For US commitments to global procurement liberalization, an easy-to-use reference is in Federal Acquisition Regulation (FAR) subpart 25.4. FAR Part 25 covers 'Foreign Acquisition' and Subpart 25.4 covers 'Trade Agreements'.
} 
be in future negotiating rounds. ${ }^{6}$

The US risked destabilization of these substantial treaty commitments to liberalize procurement markets when President Barack Obama signed the American Recovery and Reinvestment Act of 2009 into law on 19 February 2009. ${ }^{7}$ Recovery Act section 1605 forbids the use of funds appropriated by the US Congress under the Act on the 'construction, alteration, or repair of public buildings or public works unless all of the iron, steel, and manufactured goods used in the project are produced in the United States'. ${ }^{8}$ The head of a federal department or agency may waive the Buy American requirements of the Recovery Act in three circumstances. ${ }^{9}$ After considerable debate in both Houses of the US Congress, the Recovery Act passed with a provision stipulating that the new Buy American restrictions found in the Recovery Act 'shall be applied in a manner consistent with United States obligations under international agreements'. ${ }^{10}$ On 31 March 2009, the US Executive Branch promulgated in interim form a new Federal Acquisition Regulation (FAR) subpart 25.6 to implement the Recovery Act Buy American

\footnotetext{
${ }^{6}$ The attempted move in the Doha Round to a broader transparency agreement was suspended and some have argued that transparency alone is not the right approach. See S. J. Evenett and B. Hoekman, 'Government Procurement: Market Access, Transparency, and Multilateral Trade Rules', World Bank Policy Research Paper no. 3195, [2004]; J. Linarelli, 'Informing the WTO's Transparency Agenda: Law, Economics and International Relations Theory', in S. Arrowsmith and M. Trybus (eds.), Public Procurement: The Continuing Revolution, (The Hague: Kluwer Law International, 2003).

${ }^{7}$ Public Law No. 111-5, 123 Stat. 115 (17 February 2009), hereinafter referred to as the 'Recovery Act' or 'Act'.

${ }^{8}$ Recovery Act $§ 1605$.

9 The three exceptions are covered in Section 2.1. below.

${ }^{10}$ Recovery Act $\S 1605(d)$.
} 
requirements. $^{11}$ On 23 April 2009, the US Office of Management and Budget issued Interim Final Guidance to implement the Recovery Act Buy American requirements for awards of financial assistance by the US government. ${ }^{12}$ While the FAR is a uniform regulation covering US federal procurements, and FAR subpart 25.6 covers federal procurements using Recovery Act funds, the OMB Guidance covers US state and local procurements using Recovery Act funds.

This chapter has two aims. First, it will assess whether the new Buy American provision in the Recovery Act and its implementing federal regulations breach WTO commitments of the US. It will also examine whether the Buy American provisions breach FTA commitments of the US, although the FTA analysis is tangential to the WTO analysis. The initial parts of this chapter thus ask questions having to do with an actual economic crisis, in particular a particularly devastating crisis, from the effects of which the world is still reeling. In pursuit of this aim, Section 2 of this chapter explains the relevant Recovery Act provisions, their legislative history in the US Congress, and implementing federal regulations. Section 3 evaluates whether Recovery Act section 1605 and its implementing regulations breach US WTO and FTA obligations. While there has been some partial analysis of whether Recovery Act section 1605 breaches GPA

\footnotetext{
${ }^{11}$ FAR Case 2009-008, American Recovery and Reinvestment Act of 2009 (the Recovery Act) - Buy American Requirements for Construction Material, 74 Federal Register 14623-14633 (31 March 2009). The FAR is the uniform regulation covering all of US federal procurement.

${ }^{12}$ US Office of Management and Budget, Requirements for Implementing Sections 1512, 1605, and 1606 of the American Recovery and Reinvestment Act of 2009 for Financial Assistance Awards, 74 Federal Register 1844918463 (23 April 2009).
} 
commitments, there has been to-date no comprehensive analysis of the WTO legal issues. ${ }^{13}$ Section 3 explains that US trading partners have a weak argument that the US violated its GPA and FTA commitments liberalizing government procurement, but that they may have a plausible claim that the US has violated Article 3.1(b) of the WTO Subsidies and Countervailing Measures Agreement. Some countries may have, moreover, a GATT Article XXIII non-violation nullification or impairment claim, but a clear assessment of the merits of such a claim requires a good deal of further empirical research on the effects of the Buy American preference on the balance of concessions and the legitimate expectations of affected WTO members and FTA signatories in products in substantial demand under the Recovery Act, such as steel. What seems to follow from this analysis, however, is that the WTO legal system is ill equipped to respond to the economic needs of states when global economic crisis strikes.

The second aim of this chapter is to offer some tentative prescriptions for dealing with future economic crises from a trade perspective. While the overriding emphasis has been on new paradigms of financial regulation, countries should not ignore the potential for new ways of regulating international trade and procurement liberalization. Section 3 of this chapter suggests that WTO members should develop a new and narrowly tailored safeguards regime from a coordinated and multilateral standpoint specifically to deal with global economic crises. If all or

\footnotetext{
${ }^{13}$ See G. C. Hufbauer and J. J. Schott, 'Buy American: Bad for Jobs, Worse for Reputation', Peterson Institute for International Economics Policy Brief No. PB09-2 (Feb. 2009); S. L. Schooner and C. R. Yukins, 'Tempering "Buy American” in the Recovery Act - Steering Clear of a Trade War', 51 No. 10 Government Contractor 978 (March 11 , 2009); S. L. Schooner and C. R. Yukins, 'Public Procurement: Focus on People, Value for Money and Systemic Integrity, not Protectionism', in R. Baldwin and S. Evenett (eds.), The Collapse of Global Trade, Murky Protectionism, and the Crisis: Recommendations for the G20, (London: CEPR, 2009), pp.87-92.
} 
many states promulgate buy-national or other protectionist policies to stimulate their economies during economic crises, that would be another Smoot Hawley moment, resulting in a severe shrinkage of international trade and a reversal of the achievements in trade liberalization that have occurred over the past sixty years. But if states fail to coordinate their fiscal stimulus programs, then fiscal stimulus will be less effective. ${ }^{14}$ The lack of coordination might result in free riding, as states implementing stimulus measures add to their public debt while free riding states benefit from increased exports without sharing public debt burdens. The result would be that states will not promulgate stimulus programs because they cannot be assured of their effectiveness and that the benefits will flow to their citizens. While this might mean that a state's WTO and FTA obligations would be safe from the risk of violation, this is nevertheless a poor result. To promote coordination, a state could strategically implement conditional stimulus legislation, in which its procurement markets are opened on a reciprocal basis only to the exports of states that have enacted stimulus packages. Such policy coordination could preserve hardfought gains in trade liberalization, but as importantly, it may promote fiscal policy coordination during times of economic crises when such coordination is essential. The US, however, did not pursue such reciprocity, perhaps because it could not have been accomplished, or perhaps not accomplished easily or quickly.

The WTO agreements could be said to operate as constraints on future actions of WTO members. In the current institutional environment, the only tool that a state may have to engage in the sort of strategic trade policy to respond to a crisis would be under the WTO Safeguards

\footnotetext{
${ }^{14}$ See Hufbauer and Schott, note 13 above; An Interagency Statement of the United Nations System, 'Green Economy: A Transformation to Address Multiple Crises’, 25 June 2009.
} 
Agreement and the GATT Escape Clause. As explained in Section 4, safeguards arguments cannot work in response to financial or economic crises. WTO rules on safeguards were not designed to deal with such crises. This chapter proposes, however, that in times of global crisis, countries should have the means to alleviate the effects of such crises on their populations without risking breach of treaty commitments. Economic crises have the potential to increase poverty both within states and globally. The policy solutions, however, are in globally coordinated systemic risk regulation in which procurement rules and policies must play a substantial part. Expenditures of government funds relate directly to the socioeconomic justice in states and globally. To not make procurement rules and policies integral to the discussion is to omit an important tool governments must use to respond to economic crises.

\section{The US Recovery Act and Implementing Regulations}

On 17 February 2009, US President Barack Obama signed into US law the American Recovery and Reinvestment Act of $2009 .{ }^{15}$ As a response to an economic crisis, the Act is the most significant in US history, with tax and spending measures totaling US $\$ 787$ billion, and which could exceed US \$1 trillion. The Act authorizes infrastructure investment in the amount of US $\$ 150$ billion. $^{16}$

Set forth below is an explanation of the Buy American provisions found in the Act and their legislative history. The Act required implementation in federal regulation in order to be fully usable by procuring agencies in the US. Also set forth below is an analysis of the implementing regulations that are part of the US FAR. Finally, this part examines US Office of

\footnotetext{
15 Public Law No. 111-5, 123 Stat. 115 (17 February 2009).

16 Recovery.gov, 'The Act', available at www recovery.gov/?q=content/act (accessed 12 Sept. 2009).
} 
Management and Budget regulations, which impose the Buy American requirements on Recovery Act procurements that state and local governments are conducting.

\subsection{The Recovery Act's Buy American Provisions}

The initial US Buy American Act, the legislation that is widely understood or misunderstood, based on one's perspective, was passed in 1933. ${ }^{17}$ The Recovery Act Buy American provision, found in Section 1605 of the Act, is entirely new legislation. There were no attempts to make these two pieces of legislation fit together or have conceptual integrity as consolidated legislation. They are entirely separate legislative acts. Section 1605 of the Act is entitled 'Buy American' and 'Use of American Iron, Steel, and Manufactured Goods'. It forbids the use of Act funds on the construction, alteration, or repair of public buildings or public works unless all of the iron, steel, and manufactured goods used in the project are 'produced in the United States'. ${ }^{18}$ The focus of the provision is on construction because a good deal of Recovery Act funds will be spent on construction in substantial part to rehabilitate years of neglect of public infrastructure in the US by conservatives who fail to acknowledge the value of public goods. The head of a federal department or agency may waive the Buy American requirements in three circumstances: (1) it would be 'inconsistent with the public interest' to apply the Buy American requirement; (2) iron, steel, and manufactured goods are not produced in the US in 'sufficient and reasonably

\footnotetext{
${ }^{17}$ For background on the 1933 Buy American legislation, see 185 American Law Reports Federal 253 (collecting and discussing the statute, implementing regulations, and relevant case law); S. W. Feldman, Government Contracts Guidebook §§ 8.30-8.41 (Mineeapolis West, 2009). An extended discussion of the 1933 Buy American legislation is beyond the scope of this chapter.

${ }^{18}$ Recovery Act $\$ 1605(a)$.
} 
available quantities and of a satisfactory quality'; and (3) using iron, steel, and manufactured goods produced in the US will increase the overall project cost by more than 25 percent. $^{19}$ Subsection 1605(d) provides that the Buy American requirement in the Recovery Act 'shall be applied in a manner consistent with United States obligations under international agreements'. ${ }^{20}$

Section 1605 went through both Houses of the US Congress with few significant amendments, except for the addition of subsection (d), the requirement that the Buy American provisions be applied in a manner consistent with US trade agreement obligations. The original House of Representatives provision used the Buy American Act definitions of 'public work' and 'public building' to include airports, bridges, canals, dams, dikes, pipelines, railroads, multiline mass transit systems, roads, tunnels, harbors, and piers. ${ }^{21}$

The Conference Report for the final bill provides guidance to the President to use the provisions of the US legislation permitting relaxation of Buy American requirements, Title III of the Trade Agreements Act of 1979. The Conference Report advises:

Section $1605(\mathrm{~d})$ is not intended to repeal by implication the President's authority under Title III of the Trade Agreements Act of 1979. The conferees anticipate that the Administration will rely on the authority under 19 U.S.C. 2511(b) to the extent necessary to comply with US obligations under the WTO Agreement on Government Procurement and under US free trade agreements and so that section 1605 will not apply to least developed countries to the same extent that it does not

\footnotetext{
19 Ibid., at $\S 1605(\mathrm{~b})$.

${ }^{20}$ Ibid., at $\S 1605(\mathrm{~d})$

21 Recovery Act, H.R. $1,111^{\text {th }}$ Cong., $1^{\text {st }}$ sess., $§ 1110(\mathrm{~d})$.
} 
apply to the parties to those international agreements. ${ }^{22}$

The Conference Report also contains what might reasonably be read as a suggestion that the Administration should interpret 1605(d) liberally. It says: 'the conferees also note that waiver authority under section 2511(b)(2) has not been used'. ${ }^{23}$ Section 2511(b)(2), which is part of the Trade Agreements Act of 1979, gives the President the power to relax Buy American requirements for countries that are not GPA contracting parties, if those countries are not 'major industrial countries' but assume GPA obligations..$^{24}$

The US Buy American Act was passed in 1933, well before GPA and FTA commitments came into existence. The Trade Agreements Act of 1979 gives the US Executive Branch the authority to exempt from the Buy American Act procurements liberalized under the GPA and FTAs. Goods and services covered in these trade agreements are treated no differently from American goods and services. The Recovery Act of 2009, in contrast to the Buy American Act of 1933, was enacted after the GPA and FTAs came into existence. The GPA and FTAs pre-date the stimulus legislation. Both treaties and federal statutes are federal law under the US Constitution. ${ }^{25}$ The Recovery Act could have been interpreted to accept these longstanding exemptions from the Buy American Act. A long line of US federal court decisions hold that an Act of Congress supersedes an earlier-in-time international agreement or legislation only if

\footnotetext{
$22111^{\text {th }}$ Cong., $1^{\text {st }}$ sess., Congressional Record 155 H1440 (12 February 2009).

${ }^{23}$ Ibid.

${ }^{24} 19$ U.S.C. $\$ 2514$.

${ }^{25}$ The US Constitution Article VI section 2 provides that the Constitution, federal statutes, and treaties are 'the supreme law of the land'.
} 
congressional intent to do so is clear and the texts cannot fairly be read to be consistent. ${ }^{26}$ That the House version of the Recovery Act referenced the Buy American Act in defining public works and public buildings suggests that a reasonable reading would have been that the purpose of the Recovery Act was not to ignore the Buy American Act or its long established trade agreement exemptions, authorized under the Trade Agreements Act of 1979 and implemented in FAR Subpart 25.4. ${ }^{27}$ This is how an American court could have read the legislation.

There are at least three problems with this trade-agreements consistent interpretation. First, the legislative history for at least the House version of the Recovery Act may suggest a protectionist interpretation of the Act to defeat the reading of consistency with the earlier-in-time Buy American Act and international trade agreements. Second, the Buy American provisions would still have protected state and local Recovery Act procurements from international competition. The House provision would support such an interpretation, although an argument could have been made to keep procurements open that were opened when the GPA was extended to select sub-central US procurements. Third, if Congress actually intended to maintain the openness of Recovery Act procurements in a manner consistent with the international obligations of the US, what is the point of a Buy American provision in the Recovery Act? These three points cast doubt on the above interpretation.

From the initial House version of the Recovery Act came a chorus of complaints from the US's trading partners. ${ }^{28}$ When the House bill went to the Senate, Senator John McCain sought to

\footnotetext{
${ }^{26}$ The Restatements of the Law produced the American Law Institute articulates the principle. Restatement (Third) of Foreign Relations Law of the US $\S \S 114-115$ (1987).

${ }^{27}$ Recovery Act, H.R. $1,111^{\text {th }}$ Cong., $1^{\text {st }}$ sess., $§ 1110(d)$.

${ }^{28}$ Some of these are summarized in hearings before the US Senate, in Senator John McCain's testimony. $111^{\text {th }}$
} 
have the Buy American provision removed. What removal of the Buy American provision would have accomplished is unclear from a legal point of view. The pre-existing law would still apply to procurements competed with Recovery Act funds. But the removal would have had a significant effect from a political point of view. Senator Byron Dorgan offered what is in essence a compromise. He offered amendment that eventually became subsection (d), that the Buy American provision 'shall be applied in a manner consistent with United States obligations under international agreements'. ${ }^{29}$ Senator McCain characterized subsection (d) as producing a contradiction in section 1605 :

'[W]hat this amendment does is basically stand in direct contradiction to the amendment itself. It is impossible to say the section would be applied in a manner consistent with U.S. obligations under international agreements and then say that anything that is manufactured in the United States, whether iron, steel, or manufactured goods will have to be subject to "Buy American", 30

Senator Dorgan countered:

"We already have a "Buy American" provision under current law. That is not violative of our trade agreements. We just added an amendment that says this section, the "Buy American" section, "shall be applied in a manner consistent with United States obligations under international agreements".

I don't think anyone can credibly argue that somehow this undermines our international agreements. But we do have a $\$ 700$ billion-a-year trade deficit, and

\footnotetext{
Cong., $1^{\text {st }}$ sess., Congressional Record 155, n. 22, S1495-1496, S1529-1530 (4 February 2009).

${ }^{29}$ Recovery Act $\$ 1605(d)$.

${ }^{30} 111^{\text {th }}$ Cong. $1^{\text {st }}$ sess., Congressional Record 155 , no. 22, S1528 (4 February 2009).
} 
my hope would be that as we push this money out the door, we do it in support of American jobs' ${ }^{31}$

Senator Charles Grassley also countered:

'The original Buy American language in the bill doesn't specifically provide an exemption for countries that provide reciprocal access for the United States in the area of government procurement. But we are obligated under international agreements to provide such a carveout. This amendment will fix this problem.

The United States has obligations to its trading partners. If we don't live up to our commitments to other countries under trade agreements, we can't expect them to live up to their commitments to us. The last thing that we should do in this time of economic uncertainty is to fail to comply with our international obligations'. ${ }^{32}$

Governments complained during the congressional deliberations over section 1605 and Senator McCain introduced some of those complaints into the legislative history. Some of the complaints continued after the passage of section 1605, even with its 'consistent with international obligations' provision. Brazilian leaders raised concerns about the final Buy American provision. ${ }^{33}$ Brazil is a steel exporter to the US. The apparent defect in Brazil's argument, however, is that it is neither a GPA contracting party, nor does it have any FTA with

\footnotetext{
$31111^{\text {th }}$ Cong., $1^{\text {st }}$ sess., Congressional Record 155 , no. 22, S1530 (4 February 2009).

32 Ibid., at $\mathrm{S} 1528$.

${ }^{33}$ See Raymond Colitt, 'Brazil May Challenge "Buy American” at WTO', Reuters, 16 February 2009. Brazilian Foreign Minister Celso Amorim said: 'It's a complex legal analysis, but we're doing it . . Going to the WTO is a real option'.
} 
the US, China, India, and Russia also protested, but they are in the same predicament as Brazil. ${ }^{34}$ Canada, theEU, and some EU member states expressed concerns with section 1605, but they are GPA contracting parties and Canada is also a NAFTA contracting party. ${ }^{35}$ As explained in Section 3 below, these countries have a weak legal complaint under the GPA. Their complaints are apparently political, not legal, and it is in the realm of politics that their complaints might have more credence.

\subsection{The Interim FAR Regulation for Federal Government Procurements}

Of course, the devil is in the details. How do US procuring agencies interpret subsection (d) and its 'consistent with US obligations under international agreements' requirement? The Obama Administration issued Interim FAR rules on 31 March $2009 .^{36}$ The interim nature of the regulations means that they are open for comments from the public but effective immediately, as distinguished from the normal route or being proposed rules and then final rules after receipt of

34 See S. Cornwell and D. Palmer, 'U.S. Legislators Reach Deal on "Buy American"”, Reuters, 11 Feb. 2009; Hufbauer and Schott, note 13 above.

35 Some of the protestations were collected by US Senator John McCain and included in his congressional testimony opposing the Buy American preference in the Recovery Act. $111^{\text {th }}$ Cong., $1^{\text {st }}$ sess., Congressional Record 155, no. 22, S1495-1496 (4 February 2009). For a news report as of the time of the writing of this chapter, see A. Shin, “"Buy American” Puts Strain on U.S. Trade with Canada', Washington Post, 11 August 2009.

36 Federal Acquisition Regulation Case 2009-008, American Recovery and Reinvestment Act of 2009 (the Recovery Act) - Buy American Requirements for Construction Material, 74 Federal Register 14623-14639 (31 March 2009) and FAR cases following on to 2009-012. The new provisions now appear in the Federal Acquisition Regulation, the uniform-wide procurement regulation for the US federal government. This chapter will continue to cite to Federal Register references. 
comments from the public. The reason for the interim rule approach was that stimulus Act funds were ready to be awarded because the Act became effective upon enactment. ${ }^{37}$ That the Obama Administration chose the interim rule route is unremarkable, as procurement rules are often promulgated in this manner.

The US federal agencies responsible for promulgating procurement regulations found section 1605 to state unique Buy American provisions and therefore decided to promulgate a new FAR subpart 25.6, a previously reserved FAR subpart. ${ }^{38}$ It is worth going through these provisions in detail to assess US compliance with WTO and FTA obligations.

FAR 25.602 sets forth the basic policy of the Act and its implementing regulations, a general rule of prohibition of expenditures of Recovery Act funds on construction materials that are not of US origin. FAR 25.602(a) provides that except as provided in 25.603:

None of the funds appropriated or otherwise made available by the Recovery Act may be used for a project for the construction, alteration, maintenance, or repair of a public building or public work (as defined at 22.401) unless-

(1) The public building or public work is located in the US; and

(2) All of the iron, steel, and other manufactured goods used as construction material in the project are produced or manufactured in the US. ${ }^{39}$

What is produced or manufactured in the US? The new regulations do not use the substantial transformation test that is used to determine product origin for GPA and FTA

\footnotetext{
37 Ibid., at 14625.

38 Ibid., at 14624.

39 Ibid., at 14626.
} 
procurements. $^{40}$ Instead, to determine product origin, they follow an approach used for procurements of commercially available off the shelf items that are subject to traditional Buy American Act of 1933 restrictions. As to what is a product of US origin, FAR 25.602(b) provides that Recovery Act procurements ' $[\mathrm{u}] \mathrm{se}$ only domestic unmanufactured construction material, as required by the Buy American Act'. ${ }^{41}$ FAR 25.602(a)(2) requires that 'all manufacturing processes must take place in the United States, except metallurgical processes involving refinement of steel additives'. ${ }^{42}$ Like the current regulatory interpretation for commercially available off the shelf items subject to the pre-existing Buy American Act of 1933, the Recovery Act does not specify any requirements that components used in the manufacturing process be domestic. $^{43}$ The interim FAR rules thus do not require that components of manufactured products be of domestic origin. The above requirement for iron and steel does not apply to iron or steel 'used as components or subcomponents of other manufactured construction material' ${ }^{44}$ More generally, the definition of 'domestic manufactured construction material' requires manufacture in the US 'but does not include a requirement with regard to the origin of the components ${ }^{45}$ and " $[\mathrm{t}]$ here is no requirement with regard to the origin of components or

\footnotetext{
${ }^{40}$ See M. Brown, 'Meeting the Recovery Act's Buy American Standards: U.S. and Foreign Firms Face Complicated $\begin{array}{llllll}\text { Regulatory } & \text { Guidelines', } & 12 & \text { May } & \text { 2009, available }\end{array}$ http://www mayerbrown.com/globaltrade/article.asp?id=6677\&nid=5935.

4174 Federal Register at 14626.

42 Ibid.

${ }^{43}$ On the Buy American Act of 1933 definitions, see FAR 25.001(c).

4474 Federal Register at 14626.

${ }^{45}$ FAR 25.001.
} 
subcomponents in other manufactured construction material, as long as the manufacture of the construction material occurs in the United States' ${ }^{46}$ The rule of origin test for construction material differs in the regulations implementing the Buy American Act of 1933. As for manufactured construction material, regulations implementing the Buy American Act of 1933 require both manufacture in the US and that at least fifty percent of the cost of components be attributable to production in the US. ${ }^{47}$

FAR 25.603 parrots the exceptions found in section 1605(b) to the Buy American requirements. Those three exceptions are non-availability, unreasonable cost, and inconsistency with the public interest. ${ }^{48}$ What the regulations provide is more detail as to who makes the determinations as to exceptions and how those determinations are to be made. The regulations require procuring agencies to publish a notice in the Federal Register of any determination to exempt a procurement from the Recovery Act Buy American provisions. The notice is to include a detailed justification for the exemption. ${ }^{49}$

FAR 25.603(c), entitled '[a]cquisitions under trade agreements', implements Recovery Act subsection 1605(d). It refers to FAR subpart 25.4, which are the longstanding FAR provisions exempting GPA and FTA procurements from the Buy American Act of $1933 .^{50}$ Those same exemptions therefore apply to Recovery Act procurements. The Recovery Act Buy American requirements apply to construction contracts with an estimated value of at least US

\footnotetext{
4674 Federal Register at 14626.

${ }^{47}$ FAR 25.003.

${ }^{48}$ Recovery Act $\S 1605(b)$.

${ }^{49}$ FAR 25.6; 74 Federal Register at 14625.

${ }^{50}$ Ibid., at 14626-67.
} 
$\$ 7,443,000$, which is the threshold for determining GPA coverage of construction contracts and coverage for many FTAs. ${ }^{51}$

Procuring agencies are required to determine pre-award whether an exemption applies, though there are some limited exceptions for post-award determinations based on unforeseeable circumstances. ${ }^{52}$ An offeror may request a determination that section 1605 does not apply. ${ }^{53}$ For determinations based on the unreasonable cost of domestic construction material, the procuring agency must apply two standards. For iron, steel, and other manufactured construction material, the contracting officer must compare the offered price using foreign manufactured construction material to the estimated price if all domestic manufactured construction material were used. ${ }^{54}$ The contracting officer may find the cost of using domestic manufactured construction material unreasonable only if it would increase the overall offered price by more than 25 percent. ${ }^{55}$ For unmanufactured construction material, the test is the same except the threshold is six percent. ${ }^{56}$

If a procuring agency determines that the section 1605 Buy American requirements do not apply because of unreasonable cost, she must still evaluate offers that she has permitted to include foreign material. The procuring agency must increase the price evaluation factor by 25 percent overall for any offer in which foreign manufactured construction material is included, and by six percent if foreign unmanufactured construction material is included in the offer. The

\footnotetext{
51 Ibid.; FAR 25.4.

52 FAR 25.604, 25.606, 74 Federal Register at 14626.

53 FAR 25.604(a), 25.606(a), 74 Federal Register at 14627.

54 FAR 25.604(c)(1), 74 Federal Register at 14627.

55 FAR 25.605, 74 Federal Register at 14627.

56 Ibid.
} 
25 percent factor applies to the overall price and the six percent factor applies only to the cost of the foreign unmanufactured materials. ${ }^{57}$

The other two exemptions a procuring agency can declare - public interest and unavailability of domestic materials - do not require the procuring agency to evaluate any differently offers that specify foreign materials. A prominent example of the use of the public interest exemption is the waiver by the US Department of Commerce of section 1605 for specifically identified broadband equipment to be used in US \$4.7 billion designated in Recovery Act for the Broadband Technology Opportunities Program. ${ }^{58}$ Cisco Systems and Alcatel-Lucent, major suppliers of broadband technology, sought this exemption. ${ }^{59}$ For procurement involving this equipment, the evaluation factors are to be identical for offers including purely domestically manufactured equipment and those including foreign manufactured equipment. In fact, such high-technology procurements illustrate the difficulties in distinguishing domestic from foreign manufactured products. As the US Department of Commerce notice explains:

' $[\mathrm{M}] \mathrm{uch}$ of the finished products used to manage and operate broadband infrastructure and offer broadband service are manufactured outside of the United States. The manufacturing supply chain varies by product and changes constantly due to the influence of global supply and demand. The result is a very competitive and complex production landscape with components and end products being manufactured and assembled in a large number of countries. While, arguably, the

\footnotetext{
57 Ibid.

58 Broadband Technology Opportunities Program, Buy American Exception under the American Recovery and Reinvestment Act of 2009, 74 Federal Register 31410-31411 (1 July 2009).

59 'Cisco and Alcatel Oppose "Buy American” Broadband Requirements', New York Times, 16 June 2009.
} 
Secretary of Commerce could have relied on the "non-availability" exception for granting a waiver, the burden placed on the Department of Commerce in sourcing and evaluating the availability of each component of broadband equipment would be significant, and the task of sourcing and evaluating would be difficult to complete given the speed with which Congress has told NTIA to allocate the BTOP funds. In addition, requiring public entities to document the origin of broadband equipment and their components in order to determine whether they fit within the scope of the Buy American provision would severely complicate those applicants' ability to apply for funds and would place an undue burden on State and local governments. ${ }^{60}$

The global nature of manufacturing reflected in the above justification for a waiver of Buy American requirements is in large part the result of the liberalized trading regimes that the WTO agreements and FTAs have created. Similar supply chain arguments could be made about steel products. It remains to be seen how viable Buy American restrictions will be as the Recovery Act funds continue to be spent.

\subsection{Office of Management and Budget Interim Regulations for Federal Grants and State and Local Procurements}

The above discussion of the new FAR subpart 25.6 concerns the application of section 1605 Buy American provisions to federal government procurements. Federal government procurements, however, are not the only means by which Recovery Act funds are being spent. The US has a

6074 Federal Register at 31410. 
federal structure. We must also consider federal grants, which are the principal means the federal government uses to fund state and local procurements, and cooperative agreements and loans. Federal grants may also be used to fund private parties, but the relevant concern here is state and local procurements funded by federal grants.

The US Office of Management and Budget (OMB) issued interim regulations to cover federal grants. ${ }^{61}$ They are substantially similar in content to FAR subpart 25.6. The reach of the GPA and the FTAs to sub-central procurements is partial and limited, but to the extent they cover sub-central procurements, the OMB regulations exempt them from the Buy American restrictions. Notably, it is the federal agency providing the grant, and not the state or local government receiving the grant, with the power to determine whether one of the three exceptions to the Buy American requirements applies.

\section{Consistent with US Obligations Under International Agreements?}

Are FAR subpart 25.6 and the OMB interim regulations 'consistent with US obligations under international agreements'? ${ }^{62}$ Can section 1605 be implemented in a manner consistent with US obligations? There are three ways to understand this question in international economic law. First, do the Recovery Act and its implementing regulations violate any provision of a WTO agreement or an FTA? Do they carve out GPA and FTA procurements as exempt from the Buy American restrictions found in the Recovery Act? The answer is that they very likely comply

\footnotetext{
${ }^{61}$ Requirements for Implementing Sections 1512, 1605, and 1606 of the American Recovery and Reinvestment Act of 2009 for Financial Assistance Awards, Interim Final Guidance, 74 Federal Register 18448-18463 (23 April 2009).

${ }^{62}$ Recovery Act $\$ 1605(d)$.
} 
with explicit commitments relating to procurement market liberalization, as found in the GPA and in the FTAs. As explained below, the rules of origin in the regulations implementing section 1605 might produce an irrational or perverse result in which American producers are injured but not foreign producers, but this irrationality is not a violation of the GPA or FTA commitments. Second, is the Buy American preference found in section 1605 and its implementing regulations an unlawful subsidy under the WTO Subsidies and Countervailing Measures (SCM) Agreement? The answer is that it might be an unlawful 'red light' import substitution subsidy or a potentially unlawful 'yellow light' nullification or impairment subsidy, but the confidence of this result is impaired by the fact that GATT 1994 and GATS exempt procurement from general national treatment obligations. ${ }^{63}$ The only national treatment obligations applicable to procurement are for those covered by the GPA or by FTAs. ${ }^{64}$ Third, does the Buy American preference found in section 1605 and its implementing regulations violate non-violation nullification or impairment provisions, such as GATT Article XXIII and similar provisions found in various FTAs? The answer is probably not, though, as explained below, it is difficult to be certain without more data and facts on the economic effects of concessions the US granted to WTO members in the Uruguay Round. Fourth, is an exception available to the US (or any other country) to be able to suspend WTO obligations during an economic crisis? The only plausible provisions are the WTO safeguard provisions, such as those found GATT Article XIX, the WTO Safeguards Agreement, and similar FTA provisions. As explained below, a safeguard argument fails and indeed should fail. Rightly so, the Obama Administration did not attempt to make a safeguards

\footnotetext{
${ }^{63}$ WTO Subsidies and Countervailing Measures Agreement Articles 3.1; 5.

${ }^{64}$ GATT 1994 Article III.8; GPA Article III.
} 
argument. Quite apart from the implausibility of a safeguards argument from a legal standpoint, from political or economic standpoint, it could have been disastrous for the world trading system, in that it would pose the grave risk of reciprocal findings by other states, and the increase of barriers to trade at a time when such barriers would be economically counterproductive. Each of these arguments is explored below.

\subsection{No Violation of GPA Market Access Provisions}

The GPA and the procurement articles of the FTAs are the only commitments in the international trading order that open government procurements to international competition. Government procurement is exempt from national treatment obligations of a general scope as found in the GATT and GATS. From the perspective of trade liberalization, government procurement can only sensibly be evaluated under a national treatment standard, because the discrimination occurs as between foreign and domestic goods and services. All foreign goods and services could effectively be banned from all of the government procurements of a particular government and still most favored nation obligations would be met.

GATT Article III sets forth national treatment obligations for trade in goods. GATT Article III.8(a) provides that 'The provisions of this Article shall not apply to laws, regulations or requirements governing the procurement by governmental agencies of products purchased for governmental purposes and not with a view to commercial resale or with a view to use in the production of goods for commercial sale' ${ }^{65}$ As for services, GATS is similar. GATS Article XIII.1 provides that the GATS national treatment obligations 'shall not apply to laws, regulations or requirements governing the procurement by governmental agencies of services purchased for

${ }^{65}$ GATT 1994 Article III.8(a). 
governmental purposes and not with a view to commercial resale or with a view to use in the supply of services for commercial sale' ${ }^{66}$

The national treatment obligation in the GPA and in the FTAs only apply to covered government procurement. The GPA is a plurilateral agreement and WTO members do not have to agree to GPA obligations to be WTO members. ${ }^{67}$ Moreover, GPA contracting parties negotiate coverage; the GPA does not cover all government procurements of a contracting party. GPA Article III.1(a) provides that 'With respect to all laws, regulations, procedures and practices regarding government procurement covered by this Agreement, each Party shall provide immediately and unconditionally to the products, services and suppliers of other Parties offering products or services of the Parties, treatment no less favorable than . . . that accorded to domestic products, services and suppliers. . . ,68

The 'covered national treatment' approach continues in the FTAs that the US has entered with other countries. Many of these FTAs contain national treatment provisions substantially similar in content to GPA Article III. ${ }^{69}$ Some incorporate GPA Article III into their terms. ${ }^{70}$ The

${ }^{66}$ GATS XIII.1. GATS Article XIII.2 required WTO members to negotiate to include services within the scope of the GPA: 'There shall be multilateral negotiations on government procurement in services under this Agreement within two years from the date of entry into force of the WTO Agreement'. The GPA now covers services.

${ }^{67}$ Marrakesh Agreement Establishing the WTO Art. II.3. The GPA is one of the plurilateral agreements found in Appendix four of the Marrakesh Agreement.

${ }^{68}$ GPA Art. III.1(a).

${ }^{69}$ US - Australia Free Trade Agreement Chap. 15; US - Bahrain Free Trade Agreement Chap. 9; US -Chile Free Trade Agreement Chap. 9; US - Colombia Free Trade Agreement Chap. 9; Dominican Republic - Central American Free Trade Agreement Chap. 9; US- Morocco Free Trade Agreement Chap. 9; North American Free Trade Agreement Chap. 10; US - Oman Free Trade Agreement Chap. 9; US - Panama Free Trade Agreement Chap. 9; US 
national treatment provisions of these agreements tend to incorporate GATT Article III by reference into their terms. ${ }^{71}$ Some FTAs may extend national treatment beyond services and into investment. $^{72}$ Though some variation exists in the structure of the FTAs the US has entered into with other countries, they all share similar requirement: when it comes to government procurement, national treatment obligations apply only to covered procurements.

The Recovery Act and its implementing regulations found in FAR subpart 25.6 and the OMB regulations all comply with these covered national treatment obligations. They exempt for Buy American treatment all GPA and FTA procurements. GPA and FTA procurements are governed by the longstanding FAR subpart 25.4. FAR subpart 25.4, which implements US commitments under the GPA and its FTAs, has never been the subject of a challenge in a WTO dispute settlement proceeding. Whether the Recovery Act violates national treatment obligations, however, is not the end of the analysis.

- Peru Free Trade Agreement Chap 9; US - Singapore Free Trade Agreement Chap. 13; US - South Korea Free Trade Agreement Chap. 13 (pending). All of these FTAs available on the US Trade Representative website at www.ustr.gov (accessed 3 May 2010).

${ }^{70}$ The US - Singapore Free Trade Agreement is an example. NAFTA's Article 1003 on national treatment for procurement seems more extensive than what is typically found in other FTAs. Its analysis is beyond the scope of this chapter.

${ }^{71}$ NAFTA Article 301 is an example: ' 1 . Each Party shall accord national treatment to the goods of another Party in accordance with Article III of the General Agreement on Tariffs and Trade (GATT), including its interpretative notes, and to this end Article III of the GATT and its interpretative notes, or any equivalent provision of a successor agreement to which all Parties are party, are incorporated into and made part of this Agreement'. FTAs also may provide for national treatment for services. See US - Singapore Free Trade Agreement Art. 8.3.

${ }^{72}$ For example, the US - Singapore Free Trade Agreement at Article15.4 provides national treatment for investors. 


\subsection{Possible Irrational Result as to Rule of Origin Commitments}

As explained above, US federal procuring agencies use two tests to determine product origin for Buy American Act of 1933 purposes. For any commercially available off the shelf item, a domestic manufacture test is used and the origin of components is irrelevant. ${ }^{73}$ But for all other manufactured end products, including manufactured construction material, procuring agencies must determine whether the item has been manufactured in the US and whether more than fifty percent of the costs of its components is produced in the US. ${ }^{74}$ For Recovery Act procurements, the domestic manufacture test applies to manufactured construction material and manufactured end products, without regard to the origin of components. ${ }^{75}$ Thus, Recovery Act procurements share the same domestic manufacture test as Buy American Act of 1933 procurements, but for Recovery Act procurements, the test applies to any manufactured product, while for Buy American Act of 1933 procurements, the test applies only to commercial items. In contrast, to determine product origin for GPA and FTA procurements, the substantial transformation test is used. The reason for the different rules as between Buy American and Trade Agreements provisions can be found in GPA Article IV and analogous FTA articles. GPA Article IV forbids GPA contracting parties to apply rules of origin in covered government procurements 'which are different from the rules of origin applied in the normal course of trade and at the time of the transaction in question' ${ }^{76}$ Substantial transformation is the rule of origin applied in the normal

\footnotetext{
${ }^{73}$ FAR 25.001(c)(1).

74 FAR 25.001(c); 25.003.

${ }^{75}$ FAR 25.001(c)(3)(4).

${ }^{76}$ GPA Art. IV.1.
} 
course of trade. The Trade Agreements Act of 1979 requires the use of the substantial transformation test in procurements subject to GPA and FTA liberalization. ${ }^{77}$ GPA Article IV and analogous FTA articles do not obligate the US in its implementation of purely domestic laws such as the Buy American Act of 1933 or the Buy American provisions found in the Recovery Act. The Buy American provisions apply to procurements that are not subject to liberalization under any trade agreement, and the US thus can use any rule it so chooses to determine product origin.

Some odd consequences could result in the application of these rules. Consider two scenarios. First, what if a product is determined to be foreign under the domestic manufacture rule used for Recovery Act procurements, but if we apply the substantial transformation test used for GPA covered procurements, it is considered to be of US or GPA contracting party origin? For example, what if a product is determined to be from Brazil under the domestic manufacture rule, but if we apply the substantial transformation test, it would be determined to be from France, a GPA contracting party? A careful contracting officer in a US procuring agency might indeed find the product is of French origin and proceed without applying any Buy American preference. But is it not certain that a contracting officer would take such action, as the regulations do not explicitly deal with such a situation. A careful contracting officer might consider a product to be exempt from the Buy American preference if either rule of origin so provides, but the regulations do not clearly direct contracting officers to take such a position.

A potentially significant problem arises, however, not when the substantial transformation test leads to a determination that the product is from a GPA or FTA contracting

7719 U.S.C. $\$ 2518(4)(B)$. 
party, but when it leads to a determination that the product is of US origin. The domestic manufacture rule could lead to what one law firm has called a 'perverse consequence'. ${ }^{78}$ An offeror could, for example, provide iron and steel poured in Brazil, India, or China that was later substantially transformed within a GPA or FTA contracting party, and that substantially transformed product would be exempt from Buy American restrictions. However, if the substantial transformation occurred in the US, the product would be subject to the Buy American restrictions. $^{79}$ The result would be that iron and steel principally of US origin would be ineligible for use in Recovery Act procurements while steel produced entirely outside of the US would be eligible. While this result is consistent with the international obligations of the US, it fails to promote the purposes of the Recovery Act. Further, it seems to be an irrational result.

This problem is longstanding. It is not the result of the Recovery Act. It could have presented itself in procurements involving the Buy American Act of 1933 as well, particularly with respect to commercial items, which are not subject to a domestic component requirement under the regulations implementing the Buy American Act of 1933. It is the result of differences between a Buy American domestic rule of origin and a trade agreements international rule of origin. However, it is not a breach of any WTO or FTA commitment. The US government is free to impose hurdles on products of US origin.

\subsection{Possible Violation of Subsidies and Countervailing Measures Agreement}

In a discussion on the International Economic Law and Policy blog on the possible grounds for a complaint by Brazil against the US to the WTO, Debra Steger suggested that a possible cause of

\footnotetext{
${ }^{78}$ See M. Brown, note 40 above.

79 Ibid.
} 
action might be found in the import substitution subsidy prohibition found in the WTO Subsidies and Countervailing Measures (SCM) Agreement article 3.1(b). ${ }^{80}$ The question that Steger asked in her blog post is whether the Buy American provision in the Recovery Act is the worst sort of subsidy possible under the SCM Agreement. The SCM Agreement at Article 3.1 identifies so-called red light subsidies, prohibited because they always distort international trade. ${ }^{81}$ Article 3.1(a) bans export performance subsidies and 3.1(b) bans import substitution subsidies. More specifically, Article 3.1(b) provides that subsidies, 'within the meaning of Article 1', are prohibited if 'contingent, whether solely or as one of several other conditions, upon the use of domestic over imported goods'. ${ }^{82}$ Article 3.1(b) would seem to clearly prohibit Buy American requirements.

Alternatively, the Buy American preference in the Recovery Act could be a yellow light subsidy under Article 5 of the SCM Agreement, a subsidy that is potentially distorting of international trade. Article 5 provides that no WTO member 'should cause', through the use of a

${ }^{80} \mathrm{http}: / /$ worldtradelaw.typepad.com/ielpblog/2009/02/a-possible-buy-american-wto-complaint html (16 Feb. 2009). As the blogosphere and the traditional media addressed these issues, the Journal of International Economic Law published an article authored by Sue Arrowsmith and Annamaria La Chimia that deals with tied aid, a form of trade restriction that is similar to a buy national restriction in domestic procurement but with some differences. See A. La Chimia and Sue Arrowsmith, 'Addressing Tied Aid: Towards a More Development-Oriented WTO?', Journal of International Economic Law, 12 (2009), 707. The main differences between tied aid and buy national restrictions in domestic procurement is that tied aid involves external measures imposed by a donor state on a donee state, whereas a more traditionally conceived buy national measure is an internal measure imposed by a state on its own procuring entities.

81 See A. F. Lowenfeld, International Economic Law (2nd ed), (Oxford University Press, 2008), pp. 244-45.

${ }^{82}$ WTO Subsidies and Countervailing Measures (SCM) Agreement Art. 3.1(b). 
subsidy, 'adverse effects to the interests of' other WTO members. ${ }^{83}$ The adverse effects may be (a) injury to a domestic industry of the a WTO member, (b) nullification or impairment of benefits accruing directly or indirectly to other WTO members, in particular to the benefits of tariff concessions bound under GATT 1994 Article II, or (c) 'serious prejudice' to another WTO member. ${ }^{84}$ Article 5 explicitly exempts agricultural subsidies from its reach but nothing else. ${ }^{85}$

Before we can examine the effect of a governmental measure on international trade, however, we have to determine if it is a subsidy in the first place. It is not so clear and indeed it is doubtful that a Buy American restriction in government procurement is a subsidy. No Dispute Settlement Body decision has ever considered whether a buy-national preference is a subsidy. Why that is so may be because the WTO Agreements do not prohibit discrimination in government procurement unless the GPA requires national treatment. But given the placement of the particular Buy American provision under investigation here in economic stimulus legislation, a subsidies analysis seems warranted. And from the requirement of use of domestic over imported goods found in a Buy American preference, it would seem that a Buy American preference would be an unlawful import substitution subsidy. The problem with any such argument, however, is that it begs the question of what is a subsidy. The prior question that must be answered is whether a Buy American provision is a subsidy within the definition of that term found in SCM Agreement Article 1. Article 3.1 by its own terms requires that this question be answered first, in its specification that the bans of subsidies applies to subsidies 'within the

\footnotetext{
${ }^{83}$ Ibid., at Art. 5.

${ }^{84}$ Ibid.

${ }^{85}$ Ibid. ('This Article does not apply to subsidies maintained on agricultural products as provided in Article 13 of the Agreement on Agriculture.').
} 
meaning of Article 1, ${ }^{86}$

Under SCM Agreement Article 1, a subsidy exists if a government (1) confers a benefit by (2) providing a financial contribution or an income or price support. ${ }^{87}$ The Appellate Body and various Panels have made clear that these two elements are mandatory and distinct; both must be met for a subsidy to exist. ${ }^{88}$ The SCM Agreement further defines 'financial contribution' with a list of four items:

(i) a government practice involves a direct transfer of funds (e.g. grants, loans, and equity infusion), potential direct transfers of funds or liabilities (e.g. loan guarantees);

${ }^{86}$ SCM Agreement Art. 1. The SCM Agreement also requires that to be actionable, a subsidy must be 'specific', meaning 'specific to an enterprise or group of enterprises or industries'. Art. 2. It is likely that this requirement is met in the specification of construction materials for preferential treatment. See Recovery Act $§ 1605$.

${ }^{87}$ See e.g., Canada - Export Credits and Loan Guarantees for Regional Aircraft (Canada- Aircraft) WT/DS222/R, adopted 19 Feb. 2002. A third requirement, not relevant here, is that the purported subsidy must meet the specificity requirements found in Article 1.2 of the SCM Agreement. See La Chimia and Arrowsmith, note 80 above. The specificity requirement is not relevant for the analysis set forth here, as a buy national requirement clearly meets the specificity requirements.

${ }^{88}$ See Brazil - Export Financing Programme for Aircraft (Brazil--Aircraft), WT/DS46/AB/R, 2 Aug. 1999. In Brazil - Aircraft, the WTO Appellate Body considered 'financial contribution' and 'benefit' to be two separate legal elements in determining whether a subsidy exists under SCM Agreement Art. 1.1. See also Brazil - Export Financing Programme for Aircraft (Article 21.5- Canada II), WT/DS46/RW/2, adopted 23 Aug. 2001 ; US Measures Treating Export Restraints as Subsidies, (US - Export Restraints) WT/DS194/R, adopted 23 Aug. 2001. Canada - Aircraft added a third element for an export performance subsidy, which is that the subsidy must be contingent upon export performance. 
(ii) government revenue that is otherwise due is foregone or not collected (e.g. fiscal incentives such as tax credits);

(iii) a government provides goods or services other than general infrastructure, or purchases goods;

(iv) a government makes payments to a funding mechanism, or entrusts or directs a private body to carry out one or more of the type of functions illustrated in (i) to (iii) above which would normally be vested in the government and the practice, in no real sense, differs from practices normally followed by governments. ${ }^{89}$

The only one of these financial contributions to suggest that a Buy American preference might be a subsidy is item (iii), which provides that a financial contribution exists where a government or public body 'purchases goods'. ${ }^{90}$ The subsidy definition found in Article 1 also tells us that a 'price support' can meet the second element of the definition. GATT Article XVI on subsidies, which is the predecessor to the SCM Agreement, provides that a price support may reduce imports into a WTO member. ${ }^{91}$ A Buy American preference could be said to be a price support designed to reduce imports. This section will address each of these elements in turn.

\footnotetext{
${ }^{89}$ SCM Agreement Art. 1.1(a)(1).

${ }^{90}$ Ibid. 1.1(a)(1)(iii). The argument for finding a subsidy may be stronger in the case of a buy national provision in government procurement than in the case of tied aid because the purchase in question in the buy national context is by the WTO member itself imposing the restriction. In other words, the buy national provision is an internal measure. $C f$. La Chimia and Arrowsmith, note 80 above.

${ }^{91}$ GATT Art. XVI.
} 
Looking at the Dispute Settlement Body jurisprudence on financial contributions, four points relevant to the Buy American preference surface. First, not all financial contributions by government to industry are subsidies, ${ }^{92}$ a point relevant here not because a Buy American preference is a financial contribution, but because not all governmental measures conferring benefits on firms are subsidies. Second, the above items (i) through (iii) in the definition of a subsidy in the SCM Agreement limit subsidies to measures transferring economic resources from government to private enterprises. ${ }^{93}$ Third, the definition of financial contribution focuses on the nature of the government action and not on its effects. ${ }^{94}$ Thus, dispute settlement panels respect the form of governmental measures and do not re-characterize them so as to broadly encompass government measures within the subsidies definition that are not intended to be subsidies. Fourth, the subsidy definition in the SCM Agreement covers two kinds of transactions: (i) when government provides goods and services other than general infrastructure to firms; and (ii) when government purchases 'goods' from firms. ${ }^{95}$ No dispute settlement case has ever dealt with the situation where a government purchases goods.

Applying these principles, the Buy American preference in the Recovery Act might be a subsidy. It is not a financial contribution. It appears to be either the government purchasing of goods or a governmental price support. It would not be any government purchase of goods that would qualify as a subsidy, so 'ordinary' government procurement that has no intent or design to

\footnotetext{
92 US - Export Restraints, note 88 above; US - Final Countervailing Duty Determination With Respect to Certain Softwood Lumber from Canada (US-Softwood Lumber IV), WT/DS257/AB/R, 19 Jan. 2004.

93 US - Export Restraints, note 88 above.

94 Ibid.; US - Softwood Lumber IV, note 92 above.

95 US - Softwood Lumber IV, n. note 92above.
} 
stimulate a domestic economy should qualify. The Buy American preference in the Recovery Act is designed to do precisely that. The price support provision is arguably weaker, as that provision seems designed to deal with government intervention in product markets, such as in the implementation of price controls to support producers. But taking the language literally, a Buy American preference could be said to be a form of price support. ${ }^{96}$

Turning to the benefit requirement under the SCM agreement, a plausible argument can be made that the Buy American provision in the Recovery Act, and indeed any buy national restriction in government procurement, could result in a benefit, but it is doubtful that this would result in a finding that it is an unlawful subsidy. ${ }^{97}$ A buy national restriction could lead to the situation in which a domestic contractor receives a benefit in the form of an excessive price as a result of the limitation of the competition to domestic products. Article 14(d) of the SCM Agreement provides:

'The ... purchase of goods by a government shall not be considered a conferring a benefit unless ... the purchase is made for more than adequate remuneration. The adequacy of remuneration shall be determined in relation to the prevailing market conditions for the good or service in question in the country of provision or purchase. . . ,98

\footnotetext{
${ }^{96}$ For an analogous argument about tied aid, see La Chimia and Arrowsmith, note 80 above

97 The above analysis follows La Chimia and Arrowsmith, note 80 above, in substantial respects. See also P. Trepte, Regulating Procurement: Understanding the Ends and Means of Public Procurement Regulation, (Oxford University Press, 2004), p.161.

${ }^{98}$ SCM Agreeement Art. 14(d).
} 
To the extent that the contract price in a procurement subject to a buy national restriction results in the contractor receiving more than adequate remuneration, possibly caused by the restriction of competition, then a benefit indeed may have been conferred. ${ }^{99}$ A buy national restriction in this sense is discriminatory on the basis of nationality.

The US has one compelling counterargument to any claims that the Buy American preference in the Recovery Act is an unlawful subsidy under the SCM Agreement. That counterargument would be that to characterize the Buy American preference in the Recovery Act as an unlawful subsidy under the SCM Agreement is inconsistent with GATT Article III.8(a) and GATS Article XIII.1, which exempt government procurement from national treatment obligations. The US applies Buy American provisions only to products from countries not signatories to the GPA or to any FTA procurement liberalization commitments. Thus, the counterargument continues, the US may freely reject national treatment obligations for products from these countries. This interpretation, the US might argue, is the only one that ensures that the national treatment derogations for government procurement are not read entirely out of the WTO agreements and the FTAs and that the limited GPA and FTA commitments to liberalize procurement markets are not expanded beyond their agreed limits. Finally, the US could argue that it complies with all of its commitments by enforcing the consistency language of section 1605(d) in a way that gives effect to all of its WTO and FTA commitments, and which does not give undue weight to the SCM Agreement. These are compelling arguments, all of which may or may not be tested before a dispute settlement panel.

\footnotetext{
99 See La Chimia and Arrowsmith, note 80 above,.
} 


\subsection{Nonviolation Nullification or Impairment Complaint?}

In WTO jurisprudence, determining whether a treaty commitment has or has not been violated is not the end of the analysis. One should also look for so-called non-violation complaints, found in GATT Article XXIII, the aim of which is to prohibit WTO members from upsetting legitimate expectations as to the balance of concessions or negotiations. ${ }^{100}$ The question is: regardless of whether the passage and implementation by the US of the Recovery Act Buy American preference may violate any explicit WTO commitment, does it nullify or impair any other WTO commitment so as to upset the legitimate expectations of a WTO member? For example, do economic circumstances exist such that Recovery Act procurements shift steel purchases from the liberalized private sector to the protected public sector to such an extent that the balance of steel tariff concessions are nullified or impaired for a particular WTO member or members? In 2002, the US imposed tariffs on steel as safeguards measures under the WTO Safeguards Agreement and the GATT XIX, the so-called escape cause, but lost at the WTO in November $2003 .{ }^{101}$ Has the Recovery Act in any way nullified or impaired the current liberalized features of international trade in steel? While the question is posed in WTO terms, a similar analysis

100 GATT 1994 Article XXIII. See Korea - Measures Affecting Government Procurement (Korea - Procurement), WT/DS163/R, adopted 19 June 2000 for an explanation of how Article XXIII covers both concessions and negotiations.

101 See A. O. Sykes, 'The Persistent Puzzles of Safeguards: Lessons from the Steel Dispute', Journal of International Economic Law, 7 (2004), 523-64; A. O. Sykes, 'The Safeguards Mess: A Critique of WTO Jurisprudence', World Trade Review, 2 (2003), 261-95. 
would apply to FTA commitments. ${ }^{102}$

Two provisions in Article XXIII are potentially relevant. First, Article XXIII:1(b) provides a cause of action for a WTO member when that member's benefits have been nullified or impaired by another WTO's member's measure, 'whether or not that measure conflicts with the provisions' of GATT 1994. Some WTO jurisprudence on this so-called non-violation nullification or impairment cause of action exists. Article XXIII(1)(c) provides further for nullification or impairment as a result of 'the existence of any other situation', a cause of action that has never been the subject of a GATT or WTO dispute settlement proceeding. As no jurisprudence yet exists on Article $\operatorname{XXIII(1)(c),~the~focus~of~this~section~is~on~Article~}$ XXIII(1)(b), the more well-known cause of action for non-violation nullification or impairment. All that can be done here is tentative identification of the outlines of a claim of nullification or impairment by states that have negotiated procurement liberalization commitments from the US under the GPA or the FTAs, if the facts so warrant.

The three elements to an Article XXIII non-violation complaint are: (1) the application of a measure by a WTO Member; (2) a benefit accruing under the relevant WTO agreement; and (3) nullification or impairment of the benefit as a result of the application of the measure. The burden of proof is a detailed justification of all three elements, to establish a rebuttable presumption that the claim is true. ${ }^{103}$ In a Korea - Procurement, a case in which the US unsuccessfully claimed that Korea nullified or impaired benefits the US acquired in GPA

102 See, e.g., US - Singapore Free Trade Agreement Arts. 20.4.1(c), 20.4.5(a)(iii), 20.5.2, 20.6.3(b), and 20.6.4 for nullification or impairment provisions. I am grateful for Professor Chin Leng Lim for directing me to these provisions.

103 See Japan - Measures Affecting Consumer Photographic Film and Paper, WT/DS44/R, adopted 22 April 1998. 
negotiations, the panel applied Article XXIII to the GPA without controversy. ${ }^{104}$ Section 1605 and its implementation in regulations and in government purchasing is plainly a measure. Benefits accruing under WTO agreements would be any concessions or other forms of market liberalization that have now been nullified or impaired by the Buy American preference. Perhaps this inquiry could extend beyond the Buy American preference and to the Recovery Act generally. A trade ministry might ask questions as to whether significant increases in government demand for certain products has upset the balance of concessions, as it may cause price increases, reduced demand by private buyers, and reallocation of products from the liberalized private sector to the protected public sector. All of these questions demand the sort of sophisticated economic analysis that the US attempted in Japan - Measures Affecting Consumer Photographic Film and Paper, for what good it did, as the US lost that case. ${ }^{105}$ To conclude, a non-violation claim will be difficult, but a strong empirical investigation of the effects of the Recovery Act might yield at least a colorable claim.

\section{What Should States do? Coordinating for Crises}

So far, the inquiry has been mainly descriptive and doctrinal. It now turns prescriptive. What should states do in the area of procurement when economic and other crises occur? What should the WTO agreements and their FTAs permit them to do?

One place to search for answers might be in the WTO safeguards provisions, found in the GATT XIX escape clause and in the WTO Safeguards Agreement. These permit countries to

\footnotetext{
${ }^{104}$ Korea-Procurement, note 100 above.

105 See J. Linarelli, 'The Role of Dispute Settlement in World Trade Law: Some Lessons from the Kodak - Fuji Dispute', Law and Policy in International Business, 31 (2000), 263-371.
} 
impose temporary safeguards measures if, as a result of 'unforeseen developments', any product is being imported into the territory of a WTO member in such quantities and under such conditions so as to threaten serious injury to domestic producers of like or competitive products. ${ }^{106}$ These provisions, which permit temporary suspension of concessions for unexpected import surges, are not designed for economic crises. Indeed, their application in economic crisis would very likely exacerbate economic crisis to catastrophic levels. What is needed in economic crises is precisely the opposite; trade needs to expand not shrink. Import surges caused by increased government spending to alleviate the effects of an economic crisis are not the sort of surge to which the safeguards protections should apply. Safeguards arguments were unsuccessful in US attempts to protect its steel industry during the Asian Financial Crisis. ${ }^{107}$ Given that no safeguards have ever been upheld in a dispute settlement, ${ }^{108}$ it is hard to believe such a case would succeed before the WTO on the grounds of stimulating a national economy in times of economic crisis.

Safeguards in response to economic crisis should be multilateral. They should be coordinated. The Recovery Act Buy American preference took a middle route, but it may have produced better results, or at least have been more acceptable to other countries, if the US were to have included a reciprocity provision. The US had several options on the table. The middle route the US took is that it did not disregard its GPA and FTA commitments. Rather, it kept open procurements already open via these commitments, and closed the rest. The other ends of the spectrum would have been to close or open all Recovery Act procurements. But a combination of ${ }^{106}$ GATT 1994 Art. XIX; WTO Agreement on Safeguards Art. 2.1.

107 See Sykes, note 101 above.

108 See Lowenfeld, note 81 above. p. 99. 
the middle route that the US took, along with a reciprocity provision to the effect that 'if you enact stimulus measures and open up your stimulus procurements, we will open up ours' may have been the better result, particularly if coordinated ahead of time among the G20 countries. In other words, Buy American preferences would apply only to products from countries that fail to enact stimulus measures that open up their stimulus procurements to international competition.

This proposal is strategic and conceptual at this point. Much more legal and policy detail needs to be worked out. For example, what does it mean to say that a WTO member opens up their stimulus procurements? What if one WTO member puts much more stimulus funding and stimulus procurement on the table than another? These questions need to be carefully balanced against the demands of justice within domestic societies and concerns about free riding. From a political point of view or from the standpoint of the social contract, why should a government spend taxpayer funds to stimulate the economies of other countries, when there is no ex ante agreement to reciprocate? The only argument is one from the theory of comparative advantage that even unilateral liberalization would make everyone better off, but economic efficiency is not the only value at stake. What the US might rightly be accused of is a political failure to attempt to coordinate fiscal stimuli among countries, not a legal violation of international trade agreements.

\section{Conclusion}

This chapter investigates whether the US violated its WTO and FTA commitments in enacting and implementing Buy American preferences for procurements designed to stimulate its economy in response to the 2008-09 global economic crisis. The US did not violate its

procurement liberalization commitments in the WTO GPA and in FTA provisions liberalizing 
procurement markets. The Buy American preference may be an unlawful subsidy under the SCM Agreement, but the US may have a defense under the national treatment derogations found in the GATT and GATS for government procurement. It is, moreover, difficult to determine at this stage whether another state may have a viable non-violation complaint against the US. The legal analysis set forth in this chapter suggests that WTO law as it currently stands might be inadequate to the task of dealing with international trade issues that may arise in a global economic crisis. More work needs to be done at the WTO on coordinating national responses to global economic crises. In essence, that means a much stronger multilateral focus on safeguards that will promote economic growth and economic fairness.

Apart from concerns about the legality of the Buy American preference in the Recovery Act, what the US may have violated is its political commitments to the G20. The 15 November 2008 Declaration in the Summit on Financial Markets and the World Economy contained a clause 13, underscoring the "critical importance of rejecting protectionism and not turning inward in times of financial uncertainty'. ${ }^{109}$ More to the point, the G20 countries committed to the following: 'within the next 12 months, we will refrain from raising new barriers to investment or to trade in goods and services, imposing new export restrictions, or implementing new [WTO] inconsistent measures to stimulate exports'. This so-called standstill agreement is not a legal commitment. It is not a treaty. It is state practice, but does not come close to reflecting customary international law. But it is a political commitment, and the US has enacted legislation and regulation that 'raise new barriers to ... trade'.

\footnotetext{
109 Declaration, Summit on Financial Markets and the World Economy, 15 Nov. 2008, available at www.g20.org/Documents/g20 summit declaration.pdf (accessed 26 Jan. 2010).
} 
Perhaps in the future, we will see a more vigorous multilateralism. What we may have learned from the most recent economic crisis, however, is that politics is not enough. We need law - pre-existing and legally enforceable treaty commitments - to set the conditions for a reliably successful multilateral effort. 